\title{
Original Article \\ In vitro culture technique of Camellia sinensis $L$ for epicatechin production with phosphor inducer
}

\author{
Sutini $^{1 *}$, Widiwurjani ${ }^{1}$, Nora Augustien ${ }^{1}$, Hadi Suhardjono $^{1}$, Guniarti $^{1}$, Djoko Agus Purwanto ${ }^{2}$, Wirdhatul Muslihatin ${ }^{3}$ \\ ${ }^{1}$ Department of Agrotechnology, Faculty of Agriculture, UPN "Veteran" East Java, Surabaya, Indonesia. \\ ${ }^{2}$ Department of Pharmaceutical Chemistry, Faculty of Pharmacy, Universitas Airlangga, Surabaya, Indonesia. \\ ${ }^{3}$ Department of Biology, Faculty of Mathematics and Natural Sciences, Sepuluh Nopember Institute of Technology, Surabaya, Indonesia.
}

\begin{abstract}
In several ASEAN countries, in vitro culture techniques are one of the cultivation technologies that applied in sustainable agriculture. This technology has been performed in response to obtain the secondary metabolite of epicatechin from Camellia sinensis L. However, The yield of epicatechin is remaining low than in the field production. To overcome this problem, phosphor inducers is desirable to be supplemented in the study. The young leaf shoots of $C$. sinensis L was sliced on a culture-filled bottle, the sliced part was re-cultivated in the same medium by supplementing of 2,4-D growth regulators, then the medium was optimized by phosphor inducer with range of concentartions $40-200$ ppm. The callus formation was then evaluated using high performance liquid chromatography methods to obtain qualitative and quantitative data. The results showed that the yield of epicatechin was obtained to $11.75 \%$, suggesting that the supplementing of phosphor inducers at cultivation of in vitro culture of $C$. sinensis $\mathrm{L}$ able to improve the production of epicatechin by in vitro culture technique.
\end{abstract}

Keywords: Camellia sinensis L, epicatechin, in vitro culture, phosphor inducer.

Received: 23 August 2019 Revised: 14 March 2020 Accepted: 18 April 2020

\section{Introduction}

Epicatechin is one of the bioactive compounds isolated from the Camellia sinensis $\mathrm{L}$ that has several properties including anti-cancer (Kurbitz et al., 2011; Siddique et al., 2011). As anti-cancer, epicatechin able to protect neuron and cure for muscle degeneration (Ramirez-Sanchez et al., 2014; Schroeter et al., 2007). Moreover, Chang et al. (2014) showed in their study that except dealing with neurological disorders, epicatechin also serves to reduce injury to the brain. Suggesting that epicatechin can be a lowering of blood pressure and increasing relaxation (Galleano et al., 2013).

In the ASEAN countries, epicatechin is widely exploited on plantations found several problems, such as highly dependent on climatic conditions, less resistant to cold weather, highlands-dependent and required the acidity of the land. To overcome these problems, in vitro culture techniques can be applied as an alternative cultivation. In vitro culture technique is provided several interests including weather/climate-independent and short-harvested time. Neverthless, the yield of epicatechin is remaining low using In vitro culture technique compare to its field production.

To overcome the low production of this bioactive, supplementing inducers in the form of biotic elicitors or

* Corresponding Author:

Sutini

Department of Agrotechnology, Faculty of Agriculture, UPN

"Veteran" East Java, Surabaya, Indonesia.

Phone: 031-8793653 Fax: 031-8793653

e-mail: tien_basuki@yahoo.com

http://dx.doi.org/10.23869/bphjbr.25.2.20203

Published by () PBI East Java. Open Access $₫$ ww.berkalahayati.org abiotic is desirable to conduct, and engineered by using Escherichia coli and Agrobacterium rhizogenes (Zhang et al., 2007; Zhao et al., 2015). In our previous study, supplementation of abiotic elicitors such as the use of $\mathrm{Cu}$ ${ }^{2+}$ metal ion inducers (Nartop, 2018; Sutini et al., 2008) able to increase the yield of secondary metabolites (Mori et al., 2017). The addition of precursors and optimization of phosphorous can perform to stimulate the production of biomass and secondary metabolites.

Phosphor is one elements in the macro nutrients that direct the metabolic process of the nucleus and cell wall shyntesis by performing as an enzyme cofactor in the shyntesis of secondary metabolites. While in the epicatechin biosynthesis, phosphor is required in the biosynthesis of DNA, nucleus and cell wall. In the previous study, the application of $2 \mathrm{~g} \quad \mathrm{KH}_{2} \mathrm{PO}_{4}$ can improve a dry weight of withanolide-A secondary metabolites of $13.59 \mathrm{mg} \mathrm{g}^{-1}$ (Muthaiya et al., 2013). In addition to observe the role of phosphor in the biosynthesis of secondary metabolites, therefore the researchers proposed the induction of phosphor in the in vitro culture of the $C$. sinensis $\mathrm{L}$ plant cultivation. The goal of this study was to obtain secondary metabolites of epicatechin that have large amounts of bioactive properties through in vitro culture from the $C$. sinensis L. plant.

\section{Methods}

Callus initiation and subculture

Callus initiation was initially planted a young shoots of $C$. sinensis L aseptically in the culture bottle. Aseptic 
planting performed as previous method (Grout, 2017; Kumar and Chiang, 2012; Murashige and Skoog, 1962 ), the young leaves were selcted in first to the third position of leaves, then washed the leaves with the flowing water for $20 \mathrm{~min}$, then leaves were soaked using 3\% fungicides and bactericides, following soaked using 5\% sodium hypochlorite solution, then rinsed using sterile distilled water three times in a laminar air flow room. The leaves was sliced aseptically to form a callus into the MS media with partial modification. Shoots of young leaves and callus, callus subculture, were re-cultivated on MS medium with the supplementatio of growth regulators 2 , 4-D: 2, 4-diphenoxy acetic acid (2,4-D) one ppm (Galleano et al., 2013).

\section{Phosphor inducer treatment}

The medium containing 2,4-D one ppm growth regulator was optimized by supplementation of phosphor inducer with ranging concentrations. The optimizations were: a) MS media without the phosphor supplemetation, b) MS media with the phosphor supplementation at consecutive concentrations: $0,40,80,120,160,200 \mathrm{mg}$. L ${ }^{-1}$. c) Planting sliced leaf \& callus on optimization media.

Testing the epicatechin secondary metabolites qualitatively-quantitatively of $C$. sinensis $\mathrm{L}$ callus

The callus was evaluating its wet weight to collect the epicatechin data qualitatively and quantitatively regarding our previous method (Sutini et al., 2016). In brief, set up the wight of callus to $500 \mathrm{mg}$, the calus was refined by a mortar and stamper followed by hot water pouring at 75 ${ }^{\circ} \mathrm{C}$, then collect the clear solution. The callus was dissolved in $25 \mathrm{ml}$ chloroform followed by shaking using a separating funnel, resulting two layers. The top layer was collected, added with ethyl acetate, and gently shaked, then collect the top layer in the beaker. After collection, the solution was evaporated on acid cupboard until the splash stains. The stain firstly dissolved in the methanol followed by membrane filtration. The filtrate was injected into rheodin-high performance liquid chromatography (HPLC) to obtain epicatechin levels

\section{Results}

\section{Callus initiation/Callus formation}

Callus formation appears consecutively on the side from the sliced leaf explants, then the twisted shape - the basin is the relaxation form, and callus appears on the part of the cut edge to fill the entire explant that forms callus. The brief description of the callus formation is showen in the Figure 1.

\section{Phosphor inducer affect the wet weight of callus}

The supplementation of phosphat inducer with ranging concentration in order to increase the callus biomass affect the wet weight of the callus. Callus wet weight is shown in Table 1.
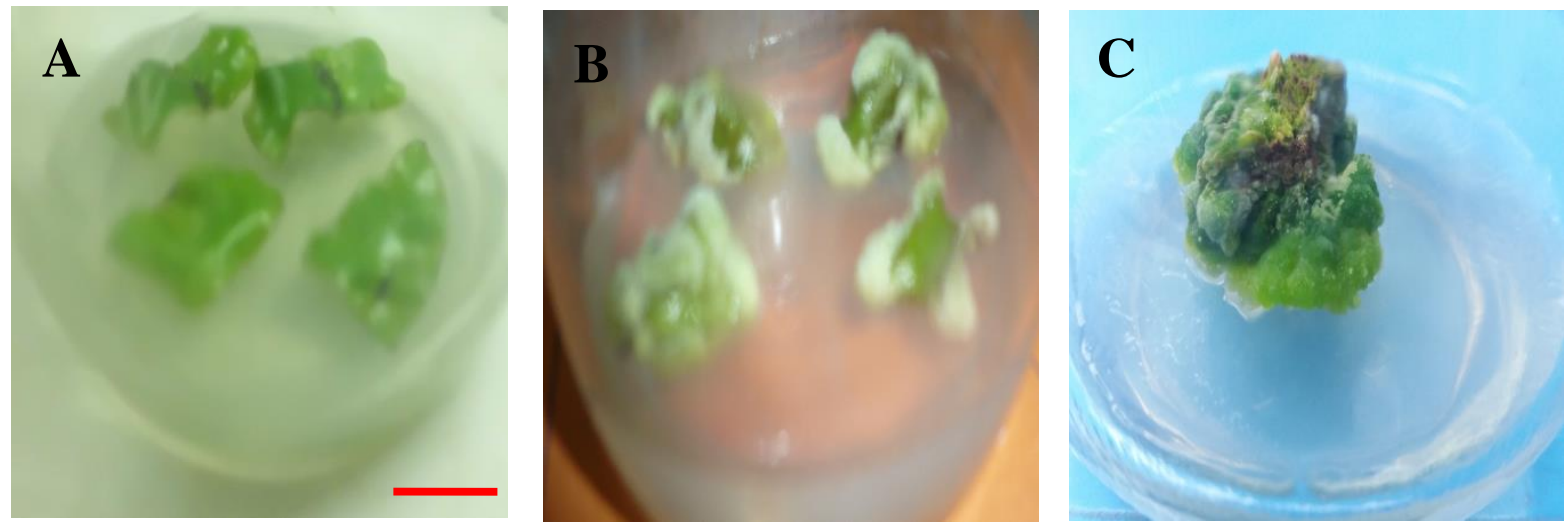

Figure 1. Callus formation. A. the shape of the explant that twists - the basin - the relaxation. B. callus appears on the cut edge. C. The overall explants that form callus, $5 \mathrm{~mm}$ bars

\section{Qualitative-quantitatively analysis of epicatechin C. sinensis $\mathrm{L}$ callus}

The qualitative data was obtained by using triocular microscopy to compare the shape \& color of callus with the standard form and color of epicatechin (Tripathi et al., 2018). In the microscope, the standard epicatechin color is relatively similar as the color of callus cells containing epicatechin (Fig. 3). Quantitative data was obtained by using High Performance Liquid Chromatography/HPLC. The standard epicatechin retention time chromatogram form with the same retention time of callus samples and obtained epicatechin levels of $11.75 \%$, as shown in Figure 4.

Table 1. Callus with inducer of variations in phosphor concentration.

\begin{tabular}{cc}
\hline Phosphor inducer $\left(\mathrm{mg}_{\mathrm{L}} \mathrm{L}^{-1}\right)$ & Wet weight of the callus $(\mathrm{mg})$ \\
\hline 0 & 50 \\
80 & 50 \\
120 & 100 \\
160 & 148 \\
200 & 200 \\
\end{tabular}



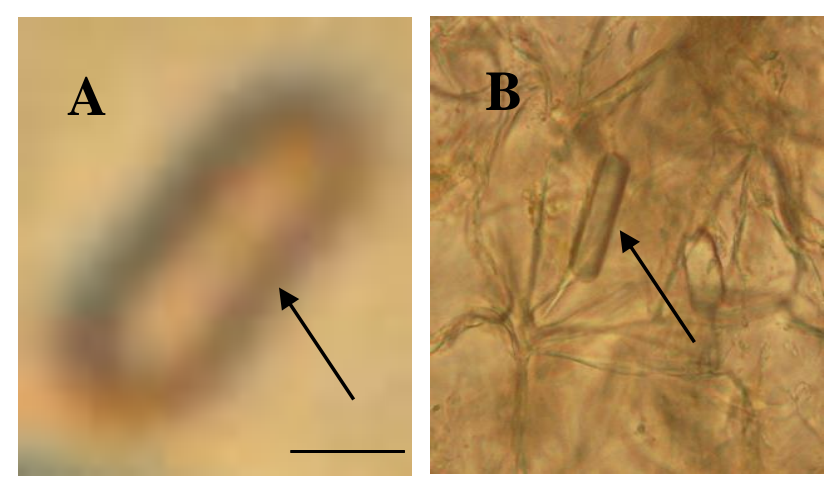

Figure 3. Epicatechin standard cells- arrow sign. A. Epicatechin callus cells- arrow sign, B. $5 \mathrm{~mm}$ bars

\section{Discussion}

In nature, callus formation formed due to cell division in explored/injured explants. Regarding to Dewi et al. (2012) the development stages was began from the formation of explants that changed from curved-rolling shape, following the changes of color leaf to older or younger, then the formation of callus on the edge of the leaf that grown on the surface of leaf explants. As shown in the Figure 1, the texture apparantly hard and compact which can be propagated to obtain the various types of secondary metabolites. In the previous study, the callus showed the hard texture after supplementing with 2,4-D growth regulators with a yellowish and aqueous color (Andre et al., 2015). In another point of view, in vitro conditions affected the callus formation which potentially used as main material for further study. Shi et al. (2011) reported that the callus formation can be regerated into the whole plants and provided a promising application in the medical and agricultural industry.

In this study, to maintain the growth of callus, the cultivation of slices young leaves and callus is required to rejuvenate, while the supplementation of regulatory substances with ranging concentration is obviously affected its cultivation which have similar statement with another study (Bidarigh and Azarpour, 2013). In vitro culture on apple plants obtained the maximum growth of callus by supplementing 2,4-D growth regulators of 2 $\mathrm{mg} / \mathrm{L}$ (Rumiyati et al., 2017), and the optimum rejuvenation of callus was carried out by treating with of 2,4-D growth regulator of one $\mathrm{mg} / \mathrm{L}$ in the embryo of Ephedra strobilacea Bunge, resulting in a significant wet weight of biomass (Mousavi et al., 2011).

Regarding to this study, the wet weight of callus increas as the increasing of phosphor concentration, as shown in the Figure 2. However, at the maximum concentration of $200 \mathrm{mg} / \mathrm{L}$, the wet weight of callus was dectrease due to the solubility of the phosphorus. In nature, this phenomonon often situated in the typical Andisol soil plantation, and the application of phosphate solubilizing bacteria, such as Bacillus mycoides, is widely applied to improve the solubality of phosphorus, resulting the depletion of phosphorus by plant roots (Setiawati et al., 2014). The additional treatment in the abiotic elicitation is relatively increased the production of secondary metabolite by cellular defense mechanism (Muthaiya et al., 2013). Despite a setting up of promoter
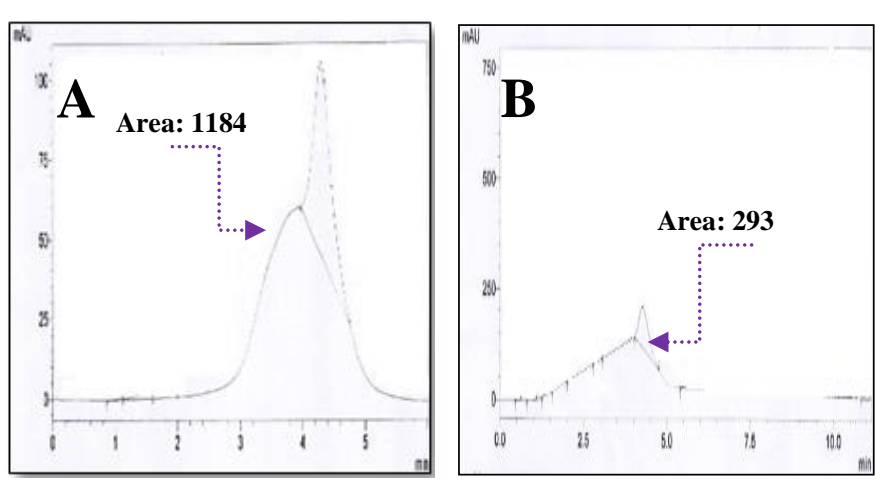

Figure 4. Chromatogram, A. Epicatechin standard, B. Epicatechin sample

in the cellular resistance also able to improve the yield of secondary metabolites (Dias et al., 2016). Khuantrairong and Traichaiyaporn (2012) reported that the supplementation of dipotassium hydrogen phosphate 5-20 $\mathrm{mg} / \mathrm{L}$ can increase the total of carotenoid and chlorophyll, and the addition of phosphor elicitor produced the highest levels of reserpine secondary metabolites in the concentration $127.5 \mathrm{mg} / \mathrm{L}$ (Supatmi, 2007).

The cell form of callus samples is apparantly having the similar color with the cell form of epicatechin standard, as shown in the Figure 3. They showed brownish yellow callus, which is desirable color in this study. The light in the incubation chamber causes oxidation of phenol compounds to epicatechin secondary metabolites. In the previous study, epicatechin is used as a comparative standard to obtain catechin secondary metabolites, with a production of $1.5 \mathrm{~g} / \mathrm{L}$ (ShibasakiKitakawa et al., 2003), suggesting the content of epicatechin in the callus. The current study have a higher yield in the content of the production epicatechin than our previous study (Sutini et al., 2016).

Quantitative data were obtained by the extraction ( $\mathrm{Su}-$ tini et al., 2018) followed by the dissolution of the dry extract using methanol pro HPLC, the extract was obtained with high purity and used for further analysis by HPLC (Sutini et al., 2016; Sutini et al., 2017). In the current study, we obtained $11.75 \%$ of epicatechin levels, as shown in the Figure 4. Interestingly, the yield of our epicatechin is closely similar to its original plant. However, at another study reported that the production of epicatechin from callus can reach at maximum levels up to $15 \%$ and $40 \%$ compared to epicatechin produced from the seeds of the cacao teobroma plant and $C$. sinensis $\mathrm{L}$ suspension culture, respectively (Eibl et al., 2018; Shibasaki-Kitakawa et al., 2003), suggesting for further modification to produce a high level of epicatechin production. The conclusion of this study that bioactive epicatechin found in $C$. sinensis $\mathrm{L}$ plants that picked from the field can also be produced through in vitro culture techniques and obtained epicatechin of $11.75 \%$. This acquisition might related to the administration of phosphorus inducers. 


\section{Acknowledgement}

We would like to thank to RISTEK DIKI Indonesia, for funding this research (Period: 2017-2018).

\section{References}

Andre, S. B., Mongomake, K., Kouassi, K. M., Edmon, K. K., Kone, T., Kouakou, T. H., \& Kouadio, Y. J. (2015). Effects of plant growth regulators and carbohydrates on callus induction and proliferation from leaf explant of Lippia multiflora Moldenke (Verbenacea). International Journal of Agriculture and Crop Sciences, 8(2), 118-127.

Bidarigh, S., \& Azarpour, E. (2013). Study effect of ba hormone levels on length shoot in-vitro Culture of tea (Camellia sinensis 1.). Journal of Agricultural and Biological Science, 8, 86-89.

Chang, C. F., Cho, S., \& Wang, J. (2014). (-)-Epicatechin protects hemorrhagic brain via synergistic Nrf2 pathways. Annals of Clinical and Translational Neurology, 1(4), 258-271. doi:10.1002/acn3.54

Dewi, I. S., Wahyuni, D. K., \& Purnobasuki, H. (2012). Perkembangan kultur daun Aglaonema sp. var Siam Pearl, Aglaonema sp. var. Lady Vilentin dan Aglaonema sp. var. Lipstik dengan perlakuan zat pengatur tumbuh IAA dan BAP. Berkala Penelitian Hayati Journal of Biological Researches, 17(2), 197-203. doi: 10.23869/bphjbr.17.2.201212

Dias, M. I., Sousa, M. J., alves, R. C., \& Ferreira, I. C. F. R. (2016) Exploring plant tissue culture to improve the production of phenolic compounds: A review. Industrial Crops and Products, 82, 9-22. doi:10.1016/j.indcrop.2015.12.016

Eibl, R., Meier, P., Stutz, I., Schildberger, D., Hühn, T., \& Eibl, D. (2018). Plant cell culture technology in the cosmetics and food industries: current state and future trends. Journal of Applied Microbiology and Biotechnology, 102(20), 8661-8675. doi: 10.1007/s00253-018-9279-8

Galleano, M., Bernatova, I., Puzserova, A., Balis, P., Sestakova, N., Pechanova, O., \& Cesar, G. F. (2013). (-)-Epicatechin reduces blood pressure and improves vasorelaxation in spontaneously hypertensive rats by NO-mediated mechanism. J. International Union of Biochemistry and Molecular Biology, 65(8), 710-715. doi:10.1002/iub.1185

Grout, B. (2017). General principles of tissue culture. In B. Thomas, B. G. Murray, D. J. Murphy (Eds.), Encyclopedia of applied plant sciences (pp. 437-443). United States: Elsevier Ltd.

Khuantrairong, T., \& Traichaiyaporn, S. (2012). Enhancement of carotenoid and chlorophyll content of an edible freshwater alga (Kai: Cladophora sp.) by supplemen-tary inorganic phosphate and investigation of its biomass production. Maejo International Journal of Science and Technology, 6(1), 1-11. doi:10.14456/mijst.2012.1

Kumar, P. P., \& Chiang, S. L. (2012). Plant tissue culture for biotechnology. National University of Singapore, Singapore. Singapore: Elsevier Inc.

Kurbitz, C., Heise, D., Redmer, T., Goumas, F, Arlt, A., Lemke, J., Rimbach, G., Kalthoff, H., \& Trauzold, A. (2011). Epicatechin gallate and catechin gallate are superior to epigallocatechin gallate in growth suppression and anti-inflammatory activities in pancreatic tumor cells. Cancer Science, 102(4):728-734. doi:10.1111/j.1349-7006.2011.01870.x

Mori, T., Wachrinrat, C., Staporn, D., Meunpong, P., Suebsai, W., Matsubara, K., Boonsri, K., Lumban, W., Kuawong, M., Phukdee T., Srifai, J., \& Boonman, K. (2017). Effects of phosphorus addition on nitrogen cycle and fluxes of $\mathrm{N}_{2} \mathrm{O}$ and $\mathrm{CH}_{4}$ in tropical tree plantation soils in Thailand. Agriculture and Natural Resources, 51(2), 91-95. doi:10.1016/j.anres.2016.03.002

Mousavi, B., Parsaeimehr, A., \& Irvani, N. (2011). Influences of growth regulators on callus induction, ephedrine and pseudoephedrine contents and chemical analysis of mature embryo of Ephedra strobilacea Bunge. Advances in Agriculture \& BotanicsInternational Journal of the Bioflux Society, 3(1), 39-45.
Murashige, T., Skoog, F. (1962). A revised medium for rapid growth and bioassays with tobacco tissue cultures. Physiologia Plantarum, 15(3), 473-497. doi:10.1111/j.1399-3054.1962.tb08052.x

Muthaiya, M. J., Nagella, P., Thiruvengadam, M., \& Mandal, A. A (2013). Enhancement of the productivity of tea (Camellia sinensis) secondary metabolites in cell suspension cultures using pathway inducers. Journal of Crop Science and Biotechnology, 16(2), 143-149. doi:10.1007/s12892-012-0124-9

Nartop P. (2018). Engineering of biomass accumulation and secondary metabolite production in plant cell and tissue cultures. In P. Ahmad, M. A. Ahanger, V. P. Singh, D. K. Tripathi, P. Alam, \& M. N. Alyemeni (Eds.), Plant metabolites and regulation under environmental stress (pp. 169-194). London: Elsevier Inc.

Ramirez-Estrada, K., Vidal-Limon, H., Hidalgo, D., Moyano, E. Golenioswki, M., Cusidó, R. M., \& Palazon, J. (2016). Elicitation, an effective strategy for the biotechnological production of bioactive high-added value compounds in plant cell factories. Molecules, 21(2), 182 doi:10.3390/molecules21020182

Ramirez-Sanchez, I., De los Santos, S., Gonzalez-Basurto, S., Canto, P., Mendoza-Lorenzo, P., Palma-Flores, C., Ceballos-Reyes, G., Villarreal, F., Zentella-Dehesa, A., \& Coral-Vazquez, R. (2014). (-)-Epicatechin improves mitochondrial-related protein levels and ameliorates oxidative stress in dystrophic dsarcoglycan null mouse striated muscle. FEBS Journal, 281(24), 5567-5580. doi:10.1111/febs.13098

Rumiyati, Sismindari, Semiarti, E., Milasari, A. F., Sari, D. K., Fitriana N., \& Galuh, S. (2017). Callus induction from various organs of dragon fruit, apple and tomato on some mediums. Pakistan Journal of Biological Sciences, 20(5), 244-252. Doi:10.3923/pjbs.2017.244.252

Schroeter, H., Bahia, P., Spencer, J. P., Sheppard, O., Rattray, M., Cadenas, E., Rice-Evans, C., Williams, R. J. (2007). (-) Epicatechin stimulates ERK-dependent cyclic AMP response element activity and up-regulates GluR2 in cortical neurons. Journal of Neurochemistry, 101(6), 1596-1606. Doi:10.1111/j.14714159.2006.04434.x

Setiawati, M. R., Wulansari, R., \& Pranoto, E. A. (2014). The comparison of effectivity from consortium bio fertilizer and endophytic bio fertilizer on productivity and health of clone mature GMB 7 tea crop. Penelitian Teh dan Kina, 17(2), 71-82. doi:10.22302/pptk.jur.jptk.v17i2.48

Shi, C. Y., Yang, H., Wei, C. L., Yu, O., Zhang, Z. Z., Jiang, C. J., Sun, J., Li, Y. Y., Chen, Q, Xia, T., \& Wan X. C. (2011). Deep sequencing of the Camellia sinensis transcriptome revealed candidate genes for major metabolic pathways of tea-specific compounds. BMC Genomics, 12, 131. doi:10.1186/1471-2164$12-131$

Shibasaki-Kitakawa, N., Takeishi, J., \& Yonemoto, T. (2003). Improvement of catechin productivity in suspension cultures of tea callus cells. Biotechnology Progress, 19(2), 655-658. doi:10.1021/bp025539a

Siddique, H. R., Liao, D. J., Mishra, S. K., Schuster, T., Wang, L., Matter, B., Campbell, P. M., Villalta, P., Nanda, S., Deng, Y., \& Saleem, M. (2011). Epicatechin-rich cocoa polyphenol inhibits Kras-activated pancreatic ductal carcinoma cell growth in vitro and in a mouse model. International Journal of Cancer, 131(7), 1720-1731. doi:10.1002/ijc.27409

Supatmi. (2007). The effects of low phosphorus concentration in Murashige skoog (MS) medium on callus growth and reseepine production of pule pandak [Rouvolfia verticillata (Lour.) Baillon]. Undergraduate Thesis. Department of Biology. Faculty of Mathematics and Science. Sebelas Maret University.

Sutini, S., Susilowati, S., Purwanto, D. A., Indra, M. R. (2016). The extraction process of Trimethyl Xanthina in vitro culture of callus Camellia sinensis with ethyl acetate solvent. MATEC Web of Conferences, 58, 01026. doi:10.1051/matecconf/20165801026

Sutini, S., Widiwurjani, W., Purwanto, D. A., \& Muslihatin, W. (2018). Polyphenon extraction process from in vitro culture of Camellia sinensis $L$ callus with ethyl alcohol. Atlantis Highlights in Engineering: International Conference on Science and Technology (ICST 2018), 1, 244-248. doi:10.2991/icst-18.2018.51 
Sutini, Sodiq, M., Muslihatin, W., \& Indra, M. R. (2017). Production of secondary metabolites trimethyl xanthina by Camellia sinensis L suspension culture. AIP Conference Proceeding. 1854, 020036. Doi:10.1063/1.4985427

Sutini, Sumitro, S. B., Cholid, R., \& Wardiyati, T. (2016). Methods of epicatechin gallate production through invitro callus Camellia sinensis L. Culture. Retrieved from The Ministry of Law and Human Rights of the Republic of Indonesia database.

Sutini, Susilowati, Indra, M. R., \& Purwanto, D. A. (2016). Growth and accumulation of flavan-3-ol in Camellia sinensis through callus culture and suspension culture method. Berkala Penelitian Hayati Journal of Biological Researches, 22(1), 27-31. doi:10.23869/bphjbr.22.1.20166

Sutini, Tatik, W., Widoretno, W., \& Sumitro, S. B. (2008). Meningkatkan produksi flavan-3-ol melalui kalus Camellia sinensis L. dengan elisator $\mathrm{Cu}^{2+}$. Berkala Penelitian Hayati Journal of Biological Researches, 14: 39-44. Doi:10.23869/bphjbr.14.1.20086

Tripathi, D., Rai, K. K., Rai, S. K., \& Rai, S. P. (2018). An improved thin cell layer culture system for efficient clonal propagation and in vitro withanolide production in a medicinal plant Withania coagulans Dunal. Industrial Crops \& Products, 119, 172-182. doi:10.1016/j.indcrop.2018.04.012

Zhang, G. H., Liang, Y. R., Jin, J., Lu, J. L., Borthakur, D., Dong, J. J., \& Zheng, X. Q. (2007). Induction of hairy roots by Agrobacterium rhizogenes in relation to L-theanine production in Camellia sinensis. Journal of Horticultural Science \& Biotechnology, 82(4), 636-640. doi 10.1080/14620316.2007.11512284

Zhao, S., Jones, J. A., Lachance, D. M., Bhan, N., Khalidi, O., Venkataraman, S., Wang, Z., \& Koffas, M. A. G. (2015). Improvement of catechin production in Escherichia coli through combinatorial metabolic engineering. Metabolic Engineering, 28, 43-53. doi:10.1016/j.ymben.2014.12.002 